\title{
THE IMPACT OF SOCIAL MEDIA MARKETING ON THE RELATIONSHIP AMONG DYNAMIC CAPABILITIES AND PERFORMANCE
}

Felipe Uribe Saavedra, Universidad EAFIT, Colombia

Joan Llonch Andreu, Universitat Autònoma de Barcelona, Spain

Josep Rialp Criado, Universitat Autònoma de Barcelona, Spain

\begin{abstract}
Online social networks have become the fastest growing phenomenon on the Internet and firms are beginning to take advantage of them as a marketing tool. However, the strategic importance of social media marketing still seems not clear, given the novelty and the difficulty of measuring their impact on business performance. This study uses data from 191 Spanish firms from several sectors, to measure the impact of the intensity of use of social media marketing on the relationship among the dynamic capabilities of market orientation and entrepreneurial orientation, and business performance. The results provide evidence that supports the moderating effects of social media marketing intensity on the strength of the mentioned relations and the importance of a strong and committed marketing strategy on digital social networks for any kind of business.
\end{abstract}

References available upon request 